\section{SCHOOL SOCIAL WORK IN THE UNITED STATES: CURRENT EVIDENCE AND FUTURE DIRECTIONS}

Susan Stone, Ph.D. University of California at Berkeley sistone@berkeley.edu

\section{TRABAJO SOCIAL EN ESCUELAS EN LOS ESTADOS UNIDOS: LA EVIDENCIA ACTUAL Y DIRECCIONES FUTURAS}

Citation/Cómo citar este artículo: Stone, S. (2015). "School Social Work in the United States: Current Evidence and Future Directions". Arbor, 191 (771): a201. doi: http://dx.doi. org/10.3989/arbor.2015.771n1003

Received: January 16, 2014. Accepted: July 25, 2014.

ABSTRACT: This paper surveys the historical and school institutional factors that shape current workforce, programmatic, and practice trends related to school social work in America. A key strand developed throughout is that the field of practice appears to be at a crossroads. It is suggested that this field of practice may be enhanced by placing the central focus on schools as organisations and school-community relations as key targets of intervention.

KEYWORDS: School social work; education; academic performance.
Copyright: @ 2015 CSIC. This is an open-access article distributed under the terms of the Creative Commons Attribution-Non Commercial (by-nc) Spain 3.0 License.
RESUMEN: Este artículo examina los factores históricos e institucionales que perfilan al personal docente, las tendencias en las programaciones y las prácticas que se desarrollan en la actualidad en el ámbito del trabajo social en la escuela en los Estados Unidos de América. Un aspecto clave derivado de este examen es que la profesión parece estar en una encrucijada. Se sugiere como alternativa a esta situación, centrar la atención y los objetivos fundamentales de intervención en las escuelas como organizaciones, y en las relaciones que se generan entre las escuelas y la comunidad.

PALABRAS CLAVE: Trabajo Social en Escuelas; la educación; el rendimiento académico. 


\section{INTRODUCTION}

School social work is a distinct field of practice within the social work profession that primarily aims to support student learning and psycho-social functioning in educational settings. School social workers adopt a diverse set of roles and tasks in schools, including direct work with students and families, consultation with school staff, and facilitation of linkage between school and community resources (Franklin, Gerlach and Chanmugan, 2008). In the last decade, numerous scholars of this subfield have called for critical reflection on this field of practice. While social work services, albeit in various forms, have been delivered in American schools for more than a century, they have been characterized as the "most overlooked" sub-field of social work practice (Allen-Meares, 2006). To date, scholars have centered their critiques on the limits of its underlying knowledge base. Although school social workers often take on a complex set of practice roles and tasks in schools that are purported to play critical roles in student psycho-social and academic well-being, relatively little is known about the determinants and outcomes of these roles and tasks (Allen-Meares and Montgomery, 2014). Most recently, American school social work scholars are attempting to characterize the central features and scope of school social work practice (Frey et al., 2012).

As an additional perspective, I offer a critique of this field of practice through a school institutional lens. Such a lens considers both the potential role of key educational policies and school institutional forces in shaping this subfield. It is typically deployed in educational research, but has not yet been systematically applied by school social work scholars (Phillippo and Stone, 2011). Prior social work scholarship acknowledges that a so-called "host" organization's mission, goals and functions will influence what and how clients are served and that predictable organizationally-related dynamics will emerge for social workers in host settings (Dane and Simon, 1991). These may include explicit or implicit discrepancies in missions and values, marginalization and isolation, and role ambiguity. From this perspective, it is crucial to review the field of school social work practice as uniquely embedded in the educational policy dynamics and within school institutional context. I will ultimately argue that application of this lens suggests that this field of practice may be better defined and its knowledge based developed by better aligning school social work services with school reform efforts. I begin my review by outlining the current policy context and history of school social work services. These provide key backdrop to re- flect on the current status and trends within the field, including a review of evidence base assessing the effects of school social work and related services.

\section{POLICY DEVELOPMENTS}

Recent policy and related research developments provide a general frame to reflect upon potential student- and school-level outcomes of social work in schools. These developments have emerged in response to concerns about the relatively poor performance of American students on international tests of readings and mathematics achievement. And those concerns have been magnified by what are described as "achievement gaps" between low-income and ethno-racial minority students and their more affluent and white majority peers across various school performance indicators, including scores on state and national standardized achievement and rates of school dropout (Rothstein, 2004; Rumberger, 2011). Similar gaps are also observed for students with significant health and mental health issues (Strompolis, Vishnevsky, Reeve, Munsell, Cook and Kilmer, 2012) and for those involved with other major children' systems of care, including those involved with the child protective services (Stone, 2007) and juvenile justice systems (Ferguson and Wolkow, 2012).

Three recent policy developments that were designed to, at least in part, respond to the achievement gap are particularly salient. The passage of No Child Left Behind (NCLB) in 2002 punctuated a significant shift in American educational policy (see Dee, Jacob, Hoxby and Ladd, 2010 for a review). It marked an expanded federal role in that it required states to set (1) standards for student academic performance, (2) assess and make transparent student performance in relationship to those standards, and (3) create accountability systems - particularly focused on schools enrolling critical densities of low income children. It also changed the performance expectations for schools from the historic emphasis on equality of access to schooling to equality of outputs, as measured by performance on standardized tests (for a review of this history, see Graham, 1993). More recent initiatives include rapid state adoption (45 of 50 states) of the rigorous Common Core Standards for student learning (Phillips and Wong, 2010) and President Obama's Race to the Top initiative, which offers competitive funds to improve low performing schools and districts (McGuinn, 2012).

Ongoing efforts to improve access to and quality of health and mental health care are also important to note. The health care debate in the United States 
implicates schools as potentially important sources of access to care (Keeton, Soleimanpour and Brindis, 2012). In addition, the New Freedom Commission, convened by former U.S. President Bush, proposed six national goals for mental health. This report specifically heightened attention to how best to coordinate mental health service delivery across education and other child serving systems (McCabe, Wertlieb and Saywitz, 2013).

The literature reflecting on the logic of these policies and their relative impacts on schools and students indicate that they have heightened pressure on school systems not only to raise student achievement levels, but also to simultaneously play key roles as access points for the delivery of health and mental health services to youth. These policies have resulted in increased scrutiny of teachers and their effectiveness (Darling-Hammond, 2010; Hanushek and Rivkin, 2010) and have (perhaps inadvertently) increased demands to demonstrate a relationship between providing access to health and mental health care and academic success (Keeton, Soleimanpour and Brindis, 2012). On the one hand, these simultaneous pressures on schools may be interpreted in a positive light in that, taken together, they reflect a holistic approach to children's needs. On the other hand, simultaneous pressure to standardize the curricular experiences while increasing responsiveness to factors that differentiate student experience (e.g., responsiveness to student health and mental health characteristics) may create the kind of incompatibility that is reflected in the historically enduring and unresolved tensions between standardization and customization as educational institutional goals (Cuban, 2012).

\section{A BRIEF HISTORICAL AND INSTITUTIONAL ACCOUNT OF SCHOOL SOCIAL WORK}

It is important to note that the field of school social work and the modern American school developed in tandem (Phillippo and Stone, 2011). Mass enrollment of students, education system centralization and bureaucratization, and school-based social services all commenced around the turn of the $20^{\text {th }}$ century, concurrent with trends of mass urbanization, industrialization and immigration. Educational and political leaders, in particular, perceived these social trends as core challenges (Tyack, 1992), as did early school social workers (Franklin, Gerlach and Chanmugam, 2008). Educational initiatives of the time sought to identify those, within the masses of new students, who did not necessarily "fit" comfortably-from their own or educator perspectives-- into schools. The strategy of differentiating and serving "misfiting" students, Tyack argues, is part and parcel of universal, bureaucratized education. Misfit students were typically "served" by interventions aimed to remedy their perceived academic failures (e.g., poor academic progress, behavior considered inappropriate). Such interventions, moreover, often took place outside the mainstream of classroom instruction or targeted whole schools perceived as serving misfit populations (Deschenes, Cuban and Tyack, 2001).

At the same time these student sorting strategies developed and expanded, a broad coalition of school reformers - those with economic efficiency and social justice interests alike-pinpointed public schools as a key intervention lever (Tyack, 1992). Specific services and service providers such as free lunch programs, school health clinics and visiting teachers (forerunners of school social workers) targeted primarily immigrant, working-class students (Tyack, 1992). The process of identifying those in need also had negative consequences-- in effect, creating stigmatizing labels of both students and their parents, often considered ignorant or neglectful for not meeting what middleclass educators viewed as basic needs (Tyack, 1992).

Following the Great Depression, as well as a threeto four-fold increase in per-pupil spending between 1930 and 1960, school social work rapidly expanded as evidenced by substantially increased expenditures and numbers of positions (Sedlak and Church, 1982). Unlike earlier school social work services, backed by the private sector, these services were funded by the state. Social work was promoted as a service not just for poor or immigrant youth, but for any child who might be slowed in their school progress by family, "nervous" or behavioral concerns (Tyack, 1992). Notably, this "reflected a significant change from the traditionally passive role of the state in educational innovation, and represented the cumulative effect of the professionalization of a number of educational and social service fields" (Sedlak and Church, 1982, p. 78). This professional reorientation depended in large part on the increased standing acquired by school social workers, based on a model in which they "treated" students much as psychologists and psychiatrists treated patients, and did so in middle and upper-middle class schools (Tyack, 1992).

This early school social work history left important legacies, in terms of both school social workers relationships to client populations as well as to schools. Early school 
social work, embedded in an era of school programming initiated by middle- and upper-class reformers, often reflected class biases that heavily influenced interpretations of children's and families' needs, values and customs. Invoking discussions around educational misfits, scholars have questioned whether youth services strove to serve or control a population that did not fit with the mainstream (Deschenes, Cuban and Tyack, 2001).

A second legacy is the organizationally-isolated nature of school social work practice. Over several decades, school social workers have practiced, not unlike teachers, apart from their school site colleagues, with a tendency to focus on individuals or small groups of students rather than on leadership or organizationlevel tasks (Allen-Meares, 1977; Allen-Meares1994). Their work, if done separately from that of teaching, resembles what Tyack (1992) describes as a "structural add-on" reform. Such reforms largely leave the work of teachers unexamined.

It is also important to underscore that schools have longstanding traditions of delivering health, psychosocial, and other related support services to student populations. Examining this history reveals, however, several underlying tensions related to these services, which have been viewed by educators and the public mainly as ancillary to the core academic mission of schools. (Adelman and Taylor, 2006; Tyack, 1992). As such, they have not been consistently funded by schools as a core component of programming and are driven by other agendas; when these services are funded from the school budget, they are typically the first to be cut or reassigned in lean budgetary times (Sedlak, 1997). For example, Frey and Dupper (2005) show how categorical funding streams (e.g., Medicaid and special education) shape the practice and delivery of social work services in schools. Similarly, such services in schools are vulnerable to co-option in tandem with institutional sorting mechanisms. Tyack (1992), to illustrate this, documents how school social workers in some districts gradually transformed into truancy officers over time. In short, there are a variety of ways in which schools resource, administer and structure health, psycho-social, and other supports for students.

Thus, in part due to these "host" setting policy and institutional dynamics, contemporary school social work is unevenly funded and the nature and quality of services vary significantly across school districts, states, and regions. This heterogeneity constrains efforts to define core parameters for this field of practice (Staudt, Cherry and Watson, 2005), though efforts to build such a model are ongoing (Frey et al., 2012).

\section{SCHOOL SOCIAL WORK AND RELATED SERVICES: CURRENT STATUS}

Schools and districts typically structure and provide student supportive services using one or more of the following strategies. Schools and districts may opt to employ social workers directly. The most recent (2007-2008) Schools and Staffing Survey identified 31,890 full time equivalent school social workers, a ratio of one school social work to 680 pupils (United States Department of Education, n.d.). The vast majority served suburban elementary schools with enrollments of less than 500 students. Less than a third were employed in schools where more than $75 \%$ of students qualified for free/ and or reduced lunch (an oft-used proxy for poverty). These estimates are somewhat lower than 2011 data compiled by the Bureau of Labor Statistics, which counted 37,050 social worker employed by elementary and secondary schools and an additional 4150 in education support services (Bureau of Labor Statistics, n.d.).

These numbers do not count social workers who may provide services to schools through formal and informal arrangements with community agencies, particularly mental health and health service providers (Franklin, 2000). The Bureau of Labor Statistics estimates that, net of the 41,200 workers employed in educational and related settings, there are 232,730 employed in child and family services in general. It is presumed that there are additional social workers in school-related roles in this larger pool as well, reflecting the fact that twenty eight of the 50 states have school social work professional associations (Frey et al., 2012).

Another common strategy is to offer services through school-based and school-linked health and mental health centers. Currently, there are 1931 known school based health centers, which typically provide some combination of primary medical care, mental/behavioral health care, dental/oral health care, health education and promotion, substance abuse counseling, case management, and nutrition education (Loflink et al., 2011). The vast majority of these (71\%) included mental health service providers, including licensed clinical social workers. It is somewhat more difficult to characterize school based mental health service delivery, because it can take many forms. A recent, nationally representative sample of United States schools finds that more than $90 \%$ of schools offer some form of mental health services to students and $87 \%$ offered these services to all students. Roughly one third (32\% and $28 \%$, respectively) reported that they only used school or district and staff or contracted with outside 
providers for services, the remainder using some combination of service providers, typically county mental health or health services agencies. Mental health services appeared most frequently in urban districts and most often targeted middle school students (Teich, Robinson and Weist, 2008).

In recent years, there has been resurging interest in so called community school models, though it is unclear what roles social workers have taken in these efforts. This model, originally developed by Leonard Covello, a school principal, at the turn of century, can take many forms. However, the foundational logic underlying this model is to fully align and integrate community services into schools in order to serve student, family and community needs. Approaches to community schools, as noted above, can vary widely. Some models focus on the co-location or coordination of community services providers to address needs of particular school communities. So-called full service school models are representative of this type of community school configuration (Dryfoos, 1994). Other models integrate community re-development strategies and school improvement strategies to raise the achievement of low income communities. The Harlem Children's Zone represents this type of strategy. Other models, such as Communities in Schools, emphasize key roles that students play in making efforts to improve their communities through a variety of service learning and voluntary opportunities. Perhaps the most comprehensive version is represented by the Coalition of Community Schools, which define a community school as "both a place and a set of partnerships between the school and other community resources and "[i]ts integrated focus on academic, health and social services, youth and community development, and community development and community engagement." The Coalition has identified 5000 community schools across 44 states.

A less frequently used model is the Comer School Develop Program, which focuses on strategic school organizational communication, teaming, planning, and management focused on the developmental needs of students. This model has been implemented in six districts in the United States (Cook, 2007).

Finally, though it is not easily considered a service delivery strategy per se, it is important to note that over the past three decades the field of prevention science has rapidly developed and matured. This literature identifies a set of (1) general and specific risk factors for problem behaviors (e.g., substance abuse, teen pregnancy, aggressive behaviors) among chil- dren and adolescents and (2) developed and tested a variety of intervention strategies to prevent or protect against the development of these behaviors, although these efforts are not adopted or implemented at full scale (see Catalano et al., 2012 for a review).

\section{SCHOOL SOCIAL WORK ROLES AND PRACTICES}

Given this overview of models of school based service delivery, what is known about school social work practice in schools? Alderson (1972) outlined four ideal types of school social work practice. The first, the traditional-clinical model, includes practices oriented to direct individual casework and group work services to students and their families. The second, the school change model, describes practice oriented towards changing or disrupting problematic school conditions. The community school model emphasizes community organization methods. Finally, the social-interaction model, places emphasis on defining target systems of interest, other systems with overlapping influences and addressing areas of fit and misfit between them. Costin (1975) attempted to unify these ideal types of practice by suggesting that social workers functioned as a critical intermediary between the school, community, and student. She stressed the central role of social work assessment of the characteristics of students, schools, and communities in terms of their capacities to support the student educational progress and well-being.

While it has been difficult to define a general set of school social work practice parameters (Staudt, Cherry and Watson, 2005), there is an ongoing initiative to develop a national practice model to better articulate the contribution of school social workers and to facilitate consistency in pre-professional training programs (Frey et al., 2012). It acknowledges the significant variability in roles and responsibilities of social works across schools, districts, and states. The model: "encourages school social workers to simultaneously 1) provide evidence-based educational, behavioral, and mental health services; 2 ) promote school climate and culture conducive to learning; and 3) maximize access to school-based and community-based resources." Further, "each of the practice features is supported by historical school social work scholarship and research that serve to delineate this specialized form of professional social work practice. The following key constructs are infused into each practice features: 1 ) Home-school-community linkages, 2) Ethical guidelines and educational policy, 3) Education rights and advocacy, and 4) Data-based decision-making." It also 
recommends a standard ratio of 1:250 students and argues that this ratio might be adjusted down for caseloads of students with intensive needs and in schools and districts with disadvantaged student populations.

Over the past four decades, there have been several notable efforts to characterize the practice-related tasks and activities of school social workers. Data collected via several national surveys of school social workers characterized the core job dimensions of school social workers and the extent to which these dimensions changed over time, provided a rank ordering of their relative importance, and estimated the frequency with which tasks associated with each job dimension was performed (Allen-Meares, 1977; Allen-Meares, 1994; Kelly et al., 2010a). In addition, Jonson-Reid \& colleagues (2004) analyzed referrals for services and services provided in Midwestern district using school administrative data. And Kelly (2008) surveyed school social workers in Illinois about the nature of interventions they provided and the extent to which these mirrored evidence-based strategies.

Three findings emerge from these studies. First, school social work referrals are complex in nature. Analysis of administrative data indicates that the three most common referral reasons include family issues, attendance problems, and academic concerns and that about a third of cases had three or more referral reasons (Jonson-Reid et al., 2004). Second, and not unexpectedly, the job dimensions of school social workers encompass a complex variety of tasks and associated roles, including administrative duties, educational counseling, coordination of community resources as well as leadership and policy making activities (Allen-Meares, 1977; Allen-Meares, 1994). Third, direct and indirect evidence generated from this work supports the contention that school social workers may gravitate towards narrow, individuallyoriented clinical approaches, reminiscent of Alderson's traditional model above. School social workers rate individual-level casework and consultation as extremely important entry level interventions (AllenMeares and Dupper, 1998) and these are precisely the services that appear to be most often provided (Jonson-Reid et al., 2004; Kelly, 2008). While practitioners rate systemic job dimensions such as leadership and policy-making as preferable, compared to other dimensions they are rated as relatively less important and frequently performed (Allen-Meares, 1977; AllenMeares, 1994; Kelly et al., 2010a).

So far, I have discussed the ways in which social work and related services are currently delivered in schools, the multiple potential roles and practices in which social workers engage, and their most typical practice strategies. This raises the key point that there are at least four sources of variation to consider in understanding potential effects of these services on potential outcomes. The first involves how a given school or district arranges services. A second source of variation is what level of the school ecology is targeted (e.g., individual students, teachers, classrooms) (see Frey and Dupper, 2005). Drawing on an integrated promotion and public health framework, a third source of variation is the population or sub-population targeted. On one hand, some strategies aim to promote the well-being of the population in general. On the other hand, "tiered" strategies are specifically designed to prevent or buffer the effect of particular risk factors in the population, including specific treatment approaches to those already showing symptoms. A fourth source of variation is the specific practice or intervention strategies utilized. In short, social work and related services in schools very much can be considered "complex interventions." This brings up important methodological and theoretical challenges (Bonnell et al., 2012; Shepperd et al., 2009). Such intervention conditions, moreover, are likely to be "modestly entitive", meaning that measured intervention effects are likely to be weak (Cook, 2007).

That being said, there are at least three types of outcomes that are hypothesized to be affected by social work and related services. One type of school social work outcome domain includes increased access to services or other community resources that could not be otherwise obtained. A second domain includes psycho-social outcomes. A third domain includes indicators of academic functioning.

There is growing pressure to show the effects of school social work interventions on academic performance. Broadly speaking, school social work interventions may directly impact academic outcomes through "readying" students for learning by reducing disruptive behaviors and emotional problems in students. A second approach, which is often indirect, occurs through interventions that have a positive effect on the school settings. Key examples of such interventions include teacher consultation, as well as classroom- peer- and school-level programming (e.g., bullying prevention and intervention, or social emotional learning activities). Another indirect approach involves interventions that influence larger school level organizational structure or processes. Schooleffects oriented educational literature, for example, 
discusses the role of creating change through school resources (e.g., financial, human capital) on both student- and school-level academic outcomes (Cohen, Raudenbush and Ball, 2003; Grubb, 2008). As members of the school staff or leadership, service providers may function as a school-level human resource, whose skills, both individually and in combination with other school personnel and resources, exert direct and indirect influences on student and school level achievement outcomes by changes to policy, procedures, processes, or structures.

The next section will briefly review what is currently known about effects of school based services. Because outcome studies span somewhat distinct literatures, I will first review evidence on effects that can specifically be linked to school social work. I will also consider effects related to service delivery strategies, including those related to (1) school based health and mental health programs, (2) community schools, and (3) the Comer School Development model. Finally, I will consider literature that evaluates school-based intervention strategies. For this discussion, I rely heavily on narrative, systematic, and meta-analytic reviews, where possible.

\section{SCHOOL SOCIAL WORK AND RELATED SCHOOL SER- VICES EFFECTS ON STUDENT AND SCHOOL OUTCOMES}

\subsection{School Social Work Effects}

Three reviews of the school social work literature have been published to date, including one narrative and two meta-analytic reviews, respectively (Early and Vonk, 2001; Franklin, Kim and Tripodi, 2009; Allen-Meares, Mongomery and Kim, 2013). AllenMeares et al. conducted an international search of what are described as Tier 1 and Tier 2 interventions. Tier 1 interventions target the student population as a whole and Tier 2 interventions target selected groups of individuals, with greater exposure to risk. Overall, they identified 18 studies that met methodological criteria. The majority of Tier 1 interventions $(n=9)$ targeted sexual and reproductive health domains $(n=4)$ and aggressive behaviors $(n=2)$. For the most part, these showed small effect sizes $(<.50)$. It is difficult to make direct conclusions about the remaining 9 Tier II studies, given heterogeneity in approach and types of outcomes considered. However, three studies that utilized group cognitive behavioral intervention targeted to "at-risk" students showed moderate effects on school grades, attendance, and classroom behaviors. Franklin and colleagues review located 21 intervention studies which reflected the first, direct mechanism of school social work practice. Fourteen of the 21 studies included in the meta-analysis reported on individual or small group formats targeting individual student change. The remaining seven studies reported on outcomes that can best be characterized as related to classroom-level interventions, including teacher consultations, a conflict mediation program, and a pregnancy prevention curriculum. Overall intervention effect sizes generated from the meta-analysis were .23 for student externalizing symptoms and .40 for student internalizing symptoms, indicating small to moderate effects. Few considered academic outcome domains. Other research has demonstrated that the addition of social work practitioners to schools are positively, albeit modestly, associated with schoollevel achievement trajectories (Stone, Shields, Hilinski and Sanford, 2013) and lowered rates of student reported theft, truancy, bullying, substance use or suspensions/expulsions (Bagley and Pritchard, 1998).

\subsection{School based health and mental health programming}

Two reviews are instructive about school based health programming. Mason-Jones et al. (2012) conducted a systematic review of 67 mostly U.S-based studies and Keeton et al. (2012) reviewed an emerging literature on school based health center (SBHC) programming. Aside from documenting the wide variety of services offered by such programming, both concluded that the presence of such programs facilitated access to health and mental health services that would not otherwise have been received, particularly for low income, minority and urban populations of students. While drawing only from quasi-experimental and observational designs, presence and/or utilization of school based health centers is promisingly associated with less medication use and activity restriction among students with asthma, more physical activity and nutritious eating patterns as well as weight loss among students with obesity, decreased depression and suicidal ideation. While there is some evidence that schools with SBHC's tend to have better climates, as measured by student and parent engagement, the quality and weight of the evidence makes it difficult to formulate strong conclusions about the outcomes of these programs (Chapman et al., 2013). In addition, both students and parents appear satisfied with services provided. Murray et al. conducted a systematic review of 17 school based health programs on academic outcomes and found mixed effects for grades and achievement, but a growing body of evidence that such programs positively influence student attendance. 
With respect to school mental health programs, it is important to note that recent epidemiological work (Merikangas et al., 2011) suggests that access to mental health care for affected children remains a problem. Only about one third of children with mental disorders received services and only those with severe symptoms received services. Children with externalizing disorders (e.g. attention-deficit/ hyperactivity disorder and behavioral disorders were most likely to access services. Although prior epidemiological work implied that schools were the most common service provider, these results suggest that specialty mental health services were the primary access point for services. In a narrative review, Hoagwood and colleagues (2007) identified 64 intervention studies focused on school based mental health services. Of these, 40 examined results for mental health outcomes only, a majority of which reported positive effects. Of the 24 that examined both mental health and academic outcomes, results were more mixed: 15 found evidence of positive effects on both academic and mental health outcomes, 8 found positive effects on mental health outcomes only and 1 found no benefits. Programs that showed positive effects on both mental health and academic outcomes were modest in size. Moreover, these interventions tended to be preventative in focus and delivered at the elementary level.

Kutash, Duchnowski and Green (2011) reviewed 148 studies focused on children classified as emotionally disturbed and receiving special education services. Although they found improvement over time in emotional and social outcomes among these children, there was, overall, little change in academic performance over time, except in schools that offered multifaceted and intensive programming. In a subsequent study, these authors found that schools that were intensively engaged in school reform activities were more likely to engage in intensive community collaborations to provide services to children, and that students with emotional disturbance in these schools had higher rates of mathematics achievement growth (Duchnowski and Kutash, 2011).

\subsection{Community Schools}

The literature on community schools is, unfortunately, thin, with one exception. Dobbie and Fryer (2011) conducted a sophisticated natural experiment assessing the impact of the Harlem Children's Zone. This program combined both community supports and services and access to a charter school. Their results suggested that the substantial achievement gains observed for students were fully attributable to access to high quality educational programming and not the community supports received.

\subsection{Comer School Developmental Model}

Two independent evaluations, using group randomized designs, of the Comer School Development Program have been conducted by Thomas Cook and his colleagues in middle schools in Prince George's County in Maryland (Cook et al., 1999) and in the Chicago Public Schools (Cook Murphy and Hunt, 2000). In both cases, schools did not fully implement all of Comer's principles. In Maryland, findings suggested greater achievement gains in schools with an explicit academic focus. In the Chicago evaluation, Comer schools had more positive social and academic climates, as rated by teachers and showed modest ( 3 percentile points) achievement gains after four years. No effects were observed for student mental health. Given the complexity of the intervention, Cook (2007) concludes that the Comer Model is a relatively successful model of school reform.

\subsection{School-based prevention}

There is firm evidence, based on well-controlled studies, which supports the efficacy of a variety of prevention strategies delivered in school settings that target aggression and violence prevention (Guerra and Bradshaw, 2008), substance and tobacco use and other health risk behaviors (Constantine, 2013) and the developmental of socio-emotional learning skills (Durlak et al., 2011). Findings from social-emotional learning programs and interventions deserve special mention, given that they have been designed to be integrated into schools and curricula particularly. The underlying logic is that schools provide natural opportunities to simultaneously learn social, emotional and cognitive skills. They specifically address five interrelated sets of cognitive, affective, and behavioral competencies: self-awareness, self-management, social awareness, relationship skills, and responsible decision making. Durlak and colleague's meta-analytic review considered program effects in five domains: social and emotional skills (ES=.57), pro-social attitudes toward self, peers, and schools (ES=.23), pro-social behavior ( $E S=.24)$, conduct problems ( $E S=.22)$, emotional distress $(E S=.24)$, and academic performance $(E S=.27)$. Most of the programs evaluated were implemented in elementary and middle schools. Pro- 
grams implemented by teachers showed consistent effects across all domains considered, but effects for socio-emotional skills were larger when delivered by non-school personnel. It is important to note that fidelity and quality of implementation moderated effect sizes. Moreover, it appears that program characteristics (not qualities of providers, schools, or communities) account for program effects (Payne and Eckert, 2010).

\section{SUMMARY}

In the brief review of effects of school social work and school based programming and intervention strategies, several themes emerge. First, although there is growing evidence to support the contention that school social work services influence key student outcomes, particularly in terms of services delivered to individuals and selected groups of students, there is limited evidence linking these services to academic outcomes. Moreover, it is unclear how the various outcomes considered relate to salient non-cognitive skills thought to be crucial to short and long term academic success and health and future employment outcomes. This is similar to findings generated in the school-based health and mental health literatures, particularly with respect to high need student populations (e.g., students classified with emotional disturbance). Indeed, several scholars in these areas (Keeton, Soleimanpour and Brindis, 2012; Hoagwood et al., 2007) express grave concern that academic outcomes have largely been overlooked in school based programming.

Second, there is a more robust literature suggesting the promise of school-based programs of prevention. In particular, social-emotional learning programs show evidence of academic achievement effects. Although relatively modest in size, these effects are consistent with those typically achieved in well-controlled educational interventions. Challenges identified in this literature include ensuring implementation fidelity and bringing these interventions to scale (Durlak et al., 2011). There is a promising set of findings, from both the school mental health and prevention literatures that adherence to evidence based principles and processes in programming and interventions represent a common ingredient in effective programming (Catalano et al., 2012; Payne and Eckert, 2010; Stephan et al., 2012). These findings represent important evidence that qualifies prior concerns that school compositional and organizational features constrain program effects (Phillippo and Stone, 2011). Such findings dovetail neatly with education system initiatives. Response to Intervention approaches seek to implement assessment driven approaches to student learning and behavioral difficulties to rapidly remediate student difficulties and to prevent entry into special education services (Kelly et al., 2010b). Similarly, the Positive Behavioral Intervention and Supports approach focuses on integrated school, classroom, and student behavioral and disciplinary approaches. Both support principles of tiered systems of evidence-based supports.

Third, it is important to note that the evidentiary base does not speak strongly to three enduring issues facing the educational system. Above, I reviewed literature that suggested that teachers and classrooms, though arguably the most important lever for academic performance, have traditionally been very difficult to penetrate and reform. It is important to note, that none of the strategies attempt to alter instructional practice directly. Rather, they focus on directly enhancing the capacities of students. Social-emotional learning programs are designed so that teachers can implement these curricula in conjunction with their regular class activities. An alternative is Robert Pianta's line of research, focused on secondary school students, which seeks to intervene with teachers directly, through an intensive coaching program that enhances the quality of student teacher interactions (Allen et al., 2011). The intervention effect size of .22 is comparable to that obtained in social emotional learning programs and is twice the size of intervention effects observed for this age group in other educational intervention studies (Hill et al., 2008). Moreover, as students of school reform often note, though processes of school reform are slow, sustained school improvement can be achieved over time through long term investments in coherent and ambitious instruction systems, the professional capacity of staff, strong relational ties between parents, the community, a student-centered learning climate, and change-oriented leadership. (Bryk et al., 2010).

Another enduring issue is the persistent achievement gap, particularly between lower and higher income students (Reardon, 2011). Although the application of universal prevention approaches may be less stigmatizing and less likely to interact with sorting structures in schools, they will do little to alter the underlying achievement distribution (Rutter and Maughan, 2002). The general range of effect sizes reported in studies reviewed-at either prevention or intervention-only account for about one-fifth to one-third of the achievement gap. 
Finally, these programming and intervention strategies do little to address the community conditions that effect access to high quality schooling. Warren (2005) has critiqued the school-community relations literature for focusing almost exclusively on service related collaboratives as opposed to either parent empowerment strategies or strategies that engage parents and educators together to collectively address community conditions.

\section{CONCLUDING COMMENTS}

I began this review by noting recent scholarship calling for critical reflection on the school social work field of practice. To date, scholars have centered their critiques on the limits of its underlying knowledge base and have attempted to characterize the central features and scope of school social work practice (Frey et al., 2012). These efforts to date center on the nature and effects of school social work services. In contrast, I suggested that school social work services be viewed through a broader school policy and institutional lens.

Such a lens provides a richer account of the heterogenous nature of school social work practice in this United States. It helps explain why, although school social work roles and tasks are potentially complex and multi-level in nature, that actual practices privilege individually-oriented case and group work interventions at the expense of school organizational interventions (Frey and Dupper, 2005; Phillippo and Stone, 2011). It also aids in revealing critical gaps in accumulated school social work and related school-based intervention literatures. I noted that accumulated intervention strategies are not optimally responsive to enduring institutional forces that isolate teaching and instructional practices from other child-focused services in schools. Moreover, these intervention strategies are only partially linked to student academic performance domains. Without such direct links, school social work and related services only partially responds to enduring achievement gaps that characterize the American education system.

Given that scholars have centered their critiques on the limits of its underlying knowledge base and have attempted to characterize the central features and scope of school social work practice (Frey et al., 2012), three potential future pathways become apparent. One is to maximize the potential of accumulated intervention effects. The provision of evidence-based tiered supports is probably the most consistent with actual school social practices and the weight of the evidence base. If this course was chosen, school social workers would emphasize their impacts on student access to the highest quality services across the spectrum of prevention to indicated services and focus on behavioral and mental health domains. While there is an evidence base supporting the efficacy of various tiered strategies (Durlak et al., 2011; Hoagwood et al., 2007; Franklin, Kim and Tripodi, 2009), academic outcomes and reduction of the achievement gap would fall out of focus. Rather, greater focus would be placed on the translation of empirical findings into to real world school settings, how to deliver these strategies in the most sustainable and efficient ways possible (Domitrovich et al., 2011), and how to integrate them with extant school initiatives such as Response to Intervention and Positive Behavioral Intervention and Supports (Kelly et al., 2010b). Attention on how to deliver such services so that they are destigmatized and do not interact with school tracking structures could be an important focus (Phillippo and Stone, 2011).

A second choice would be to revitalize the community-centric practices of some school social work practitioners of the 1920s. Shaffer (2006) documented the parent engagement and community organization practices that shaped this strand of social work services, but cautions that such roles may not be compatible with the school and district organizational goals. The knowledge base here is thin, but there are some examples of more contemporaneous applications of such strategies (Anderson-Butcher et al., 2010). Such a focus would potentially re-articulate the role of school social workers as community workers (Warren, 2005).

To be maximally responsive to enduring institutional forces, school social workers could focus on teacher interactions with students and instructional processes. Indeed, there is growing consensus that work with teachers is under-developed (O'Brien et al., 2011). Such an approach would likely demand very different pre-professional preparation, which by definition, would focus on developing school social work expertise in teaching practices and strategies for teacher professional development. Phillippo and Blosser (2013) contend that this may have consequences for re-defining school social work services, not as a social workfield of practice, but as an interstitial field spanning social work and education.

In summary, this review suggests that additional reflection is needed about whether and how school social work services ought to relate to school policy and institutional forces. It raises questions about whether this field of practice should formally organize to address the achievement gap, which would highlight alignment with teachers' work and school reform efforts. 


\section{REFERENCES}

Adelman, H. S., and Taylor, L. (2006). Menta health in schools and public health. Public Health Reports, 121, 3, pp. 294-298.

Alderson, J. (1972). Models of school social work practice. In Sarri, R. and Maple, F. F. (eds.). The school in the community. Washington, DC: NASW Press, pp. 33-36.

Allen, J. P., Pianta, R. C., Gregory, A., Mikami, A. Y. and Lun, J. (2011). An interaction-based approach to enhancing secondary school instruction and student achievement. Science, 333(6045), pp. 1034-1037. http://dx.doi.org/10.1126/ science.1207998

Allen-Meares, P (1977). Analysis of tasks in school social work. Social Work, 22, 3, pp. 196-201.

Allen-Meares, P. (1994). Social work services in schools: A national study of entry-level tasks. Social Work, 39, 5, pp. 560-565.

Allen-Meares, P. (2006). One hundred years: A historical analysis of social work services in schools. School Social Work Journal, 30, pp. 24-43.

Allen-Meares, P. and Dupper, D. R. (1998). A national study of knowledges, skills, and abilities: Curriculum development for practice in schools. Journal of Teaching in Social Work, 17, 1-2, pp. 101-119. http://dx.doi.org/10.1300/ J067v17n01_08

Allen-Meares, P. and Montgomery, K. L. (2014). Global trends and school-based social work. Children \& Schools. Advance online publication. http://dx.doi. org/10.1093/cs/cdu007

Allen-Meares, P., Montgomery, K. L. and Kim, J. S. (2013). School-based social work interventions: A cross-national systematic review. Social Work, 58, 3, pp. 253-262. http://dx.doi.org/10.1093/ sw/swt022

Anderson-Butcher, D., Lawson, H. A., lachini, A., Bean, G., Flaspohler, P. D. and Zullig, K. (2010). Capacity-related innovations resulting from the implementation of a community collaboration model for school improvement. Journal of Educational and Psychological Consultation, 20, 4, pp. 257-287. http://dx.doi. org/10.1080/10474412.2010.500512

Bagley, C. and Pritchard, C. (1998). The reduction of problem behaviours and school exclusion in at-risk youth: An experimental study of school social work with cost-benefit analyses. Child and
Family Social Work, 3, pp. 219-226. http://dx.doi.org/10.1046/j.13652206.1998.00101.x

Bonell, C., Fletcher, A., Morton, M., Lorenc, T. and Moore, L. (2012). Realist randomised controlled trials: a new approach to evaluating complex public health interventions. Social Science \& Medicine, 75, 12, pp. 2299-2306. http://dx.doi.org/10.1016/j.socscimed.2012.08.032

Bryk, A. S., Sebring, P. B., Allensworth, E. Easton, J. Q. and Luppescu, S. (2010). Organizing schools for improvement: Lessons from Chicago. Chicago, IL: University of Chicago Press.

Bureau of Labor Statistics, U. S. Department of Labor, Occupational Outlook Handbook, 2012-13 Edition, Social Workers.

Catalano, R. F., Fagan, A. A., Gavin, L. E., Greenberg, M. T., Irwin Jr, C. E., Ross, D. A. and Shek, D. T. (2012). Worldwide application of prevention science in adolescent health. The Lancet, 379 (9826), pp. 1653-1664. http://dx.doi. org/10.1016/S0140-6736(12)60238-4

Chapman, R. L., Buckley, L., Sheehan, M. and Shochet, I. (2013). School-based programs for increasing connectedness and reducing risk behavior: A systematic review. Educational Psychology Review, 25, 1, pp. 95-114. http://dx.doi. org/10.1007/s10648-013-9216-4

Cohen, D. K., Raudenbush, S. W. and Ball, D. L. (2003). Resources, instruction, and research. Educational Evaluation and Policy Analysis, 25, 2, pp. 119-142. http://dx.doi. org/10.3102/01623737025002119

Constantine, N. A. (2013). Intervention effectiveness research in adolescent health psychology: methodological issues and strategies. In Lerner, R. M. and Steinberg, L. (eds.). Handbook of Adolescent Health Psychology. New York, NY: Springer, pp. 295-322. http://dx.doi. org/10.1007/978-1-4614-6633-8_20

Conti, G., Heckman, J. and Urzua, S. (2010). The education-health gradient. The American Economic Review, 100, 2, pp. 234-238. http://dx.doi.org/10.1257/ aer.100.2.234

Cook, T. D. (2007). School based management: A concept of modest entitivity with modest results. Journal of Personnel Evaluation in Education, 20, 3-4, pp.
129-145. http://dx.doi.org/10.1007/ s11092-007-9049-0

Cook, T. D., Habib, F. N., Phillips, M., Settersten, R. A., Shagle, S. C. and Degirmencioglu, S. M. (1999). Comer's school development program in Prince George's County, Maryland: A theory-based evaluation. American Educational Research Journal, 36, 3, pp. 543-597. http://dx.doi. org/10.3102/00028312036003543

Cook, T. D., Murphy, R. F. and Hunt, H. D. (2000). Comer's School Development Program in Chicago: A theory-based evaluation. American Educational Research Journal, 37, 2, pp. 535-597. http://dx.doi. org/10.3102/00028312037002535

Costin, L. B. (1975). School social work practice: A new model. Social Work, 20, 2, pp. 135-139.

Cuban, L. (2012). Standards vs. customization: Finding the balance. Educational Leadership, 69, 5, pp. 10-15.

Cunha, F. and Heckman, J. J. (2009). The economics and psychology of inequality and human development. Journal of the European Economic Association, 7, 2-3, pp. 320-364. http://dx.doi. org/10.1162/JEEA.2009.7.2-3.320

Dane, B. O. and Simon, B. L. (1991). Resident guests: Social workers in host settings. Social Work, 36, 3, pp. 208-213.

Darling-Hammond, L. (2010). Teacher education and the American future. Journal of Teacher Education, 61, 1-2, pp. 35-47. http://dx.doi. org/10.1177/0022487109348024

Dee, T. S. and Jacob, B. A. (2010). The impact of no child left behind on students, teachers, and schools. Brookings Papers on Economic Activity, pp. 149-194. http://dx.doi.org/10.1353/ eca.2010.0014

Dee, T. S. ans Jacob, B. (2011). The impact of No Child Left Behind on student achievement. Journal of Policy Analysis and management, 30, 3, pp. 418-446. http://dx.doi.org/10.1002/pam.20586

Deschenes, S., Cuban, L. and Tyack, D. (2001). Mismatch: Historical perspectives on schools and students who don't fit them. The Teachers College Record, 103, 4, pp. 525-547. http://dx.doi. org/10.1111/0161-4681.00126 
Dobbie, W. and Fryer Jr., R. G (2011). Are high-quality schools enough to increase achievement among the poor? Evidence from the Harlem Children's Zone. American Economic Journal: Applied Economics, 3, 3, pp. 158-187.

Domitrovich, C. E., Bradshaw, C. P., Greenberg, M. T., Embry, D., Poduska, J. M. and lalongo, N. S. (2010). Integrated models of school-based prevention: Logic and theory. Psychology in the Schools, 47, 1, pp. 71-88.

Dryfoos, J. G. (1994). Full-service schools: A revolution in health and social services for children, youth, and families. New York, NY: Jossey-Bass.

Duchnowski, A. J. and Kutash, K. (2011). School reform and mental health services for students with emotional disturbances educated in urban schools. Education and Treatment of Children, 34, 3, pp. 323-346. http://dx.doi. org/10.1353/etc. 2011.0020

Durlak, J. A., Weissberg, R. P., Dymnicki, A. B., Taylor, R. D. And Schellinger, K. B. (2011). The impact of enhancing students' social and emotional learning: A meta-analysis of school-based universal interventions. Child Development, 82, 1, pp. 405-432. http://dx.doi. org/10.1111/j.1467-8624.2010.01564.x

Early, T. J. and Vonk, M. E. (2001). Effectiveness of school social work from a risk and resilience perspective. Children \& Schools, 23, 1, pp. 9-31. http://dx.doi. $\operatorname{org} / 10.1093 / c s / 23.1 .9$

Ferguson, H. B. and Wolkow, K. (2012). Educating children and youth in care: A review of barriers to school progress and strategies for change. Children and Youth Services Review, 34, 6, pp. 11431149. http://dx.doi.org/10.1016/j. childyouth.2012.01.034

Franklin, C. (2000). Predicting the future of school social work practice in the new millennium. Children \& Schools, 22, 1, pp. 3-7. http://dx.doi.org/10.1093/ $\mathrm{cs} / 22.1 .3$

Franklin, C., Gerlach, B. and Chanmugam, A. (2008). School social work. Comprehensive Handbook of Social Work and Social Welfare. New York: Wiley, pp. 205-226.

Franklin, C., Kim, J. S. and Tripodi, S. J. (2009). A meta-analysis of published school social work practice studies 19802007. Research on Social Work Practice, 19, 6, pp. 667-677. http://dx.doi. org/10.1177/1049731508330224
Frey, A. J., Alvarez, M. E., Sabatino, C. A., Lindsey, B. C., Dupper, D. R., Raines, J. C., Streeck, F., Mclnerney, A. and Norris, M. P. (2012). The development of a National School Social Work Practice Model. Children \& Schools, 34, 3, pp. 131-134. http://dx.doi.org/10.1093/cs/cds025

Frey, A. J. and Dupper, D. R. (2005). A broader conceptual approach to clinical practice for the 21st century. Children \& Schools, 27, 1, pp. 33-44. http://dx.doi. org/10.1093/cs/27.1.33

Graham, P. A. (1993). What America has expected of its schools over the past century. American Journal of Education, 101, 2, pp. 83-98.

Grubb, W. N. (2008). Multiple resources, multiple outcomes: Testing the "improved" school finance with NELS88. American Educational Research Journal, 45, 1, pp. 104-144. http://dx.doi. org/10.3102/0002831207308636

Guerra, N. G. and Bradshaw, C. P. (2008). Linking the prevention of problem behaviors and positive youth development: Core competencies for positive youth development and risk prevention. New Directions for Child and Adolescent Development, 122, pp. 1-17. http://dx.doi.org/10.1002/cd.225

Hanushek, E. A. and Rivkin, S. G. (2010). Generalizations about using valueadded measures of teacher quality. The American Economic Review, 100, 2, pp. 267-271. http://dx.doi.org/10.1257/ aer.100.2.267

Heckman, J. J. and Kautz, T. (2012). Hard evidence on soft skills. Labour economics, 19, 4, pp. 451-464. http://dx.doi. org/10.1016/j.labeco.2012.05.014

Hill, C. J., Bloom, H. S., Black, A. R. and Lipsey, M. W. (2008). Empirical benchmarks for interpreting effect sizes in research. Child Development Perspectives, 2, 3, pp. 172-177. http://dx.doi. org/10.1111/j.1750-8606.2008.00061.x

Hoagwood, K. E., Olin, S. S., Kerker, B. D., Kratochwill, T. R., Crowe, M. and Saka, N. (2007). Empirically based school interventions targeted at academic and mental health functioning. Journal of Emotional and Behavioral Disorders, 15, 2, pp. 66-92. http://dx.doi.org/10.1177 /10634266070150020301

Jonson-Reid, M., Kontak, D., Citerman, B. Essma, A. and Fezzi, N. (2004). School social work case characteristics, services, and dispositions: Year one results.
Children \& Schools, 26, 1, pp. 5-22. http://dx.doi.org/10.1093/cs/26.1.5

Keeton, V., Soleimanpour, S. and Brindis, C. D. (2012). School-based health centers in an era of health care reform: Building on history. Current Problems in Pediatric and Adolescent Health Care, 42, 6, pp. 132-156. http://dx.doi.org/10.1016/j. cppeds.2012.03.002

Kelly, M. S. (2008). The Domains and Demands of School Social Work Practice: A Guide to Working Effectively with Students, Families and Schools. New York: Oxford University Press.

Kelly, M. S., Berzin, S. C., Frey, A., Alvarez, M., Shaffer, G. and O'Brien, K. (2010a). The state of school social work: Findings from the national school social work survey. School Mental Health, 2, 3, pp. 132-141. http://dx.doi.org/10.1007/ s12310-010-9034-5

Kelly, M. S., Frey, A. J., Alvarez, M., Berzin, S. C., Shaffer, G. and O'Brien, K. (2010b). School social work practice and response to intervention. Children \& Schools, 32, 4, pp. 201-209.

Kutash, K., Duchnowski, A. J. and Green, A. L. (2011). School-based mental health programs for students who have emotional disturbances: Academic and social-emotional outcomes. School Mental Health, 3, 4, pp. 191-208. http://dx.doi.org/10.1007/s12310011-9062-9

Lofink, H., Kuebler, J., Juszczak, L., Schlitt, J., Even, M., Rosenberg, J. and White, I. (2011). 2010-2011 School-Based Health Alliance Census Report. Washington, D. C.: School-Based Health Alliance.

Mason-Jones, A. J., Crisp, C., Momberg, M., Koech, J., De Koker, P. and Mathews, C. (2012). A systematic review of the role of school-based healthcare in adolescent sexual, reproductive, and mental health. Systematic reviews, 1, 1, pp. 1-13.

McCabe, M. A., Wertlieb, D. and Saywitz, K. (2013). Promoting Children's Mental Health: The Importance of Collaboration and Public Understanding. In Child and Family Advocacy. New York: Springer, pp. 19-34.

McGuinn, P. (2012). Stimulating reform: Race to the Top, competitive grants and the Obama education agenda. Educational Policy, 26, 1, pp. 136-159. http://dx.doi. org/10.1177/0895904811425911 
Merikangas, K. R., He, J. P., Burstein, M. Swendsen, J., Avenevoli, S., Case, B. and Olfson, M. (2011). Service utilization for lifetime mental disorders in US adolescents: Results of the National Comorbidity Survey-Adolescent Supplement (NCS-A). Journal of the American Academy of Child \& Adolescent Psychiatry, 50, 1, pp. 32-45. http://dx.doi. org/10.1016/j.jaac.2010.10.006

O’Brien, K. H. M., Berzin, S. C., Kelly, M. S. Frey, A. J., Alvarez, M. E. and Shaffer, G. L. (2011). School social work with students with mental health problems: Examining different practice approaches. Children \& Schools, 33, 2, pp. 97-105. http://dx.doi.org/10.1093/cs/33.2.97

Payne, A. A. and Eckert, R. (2010). The relative importance of provider, program, school, and community predictors of the implementation quality of schoolbased prevention programs. Prevention Science, 11, 2, pp. 126-141. http:// dx.doi.org/10.1007/s11121-009-0157-6

Phillips, V. and Wong, C. (2010). Tying together the common core of standards, instruction, and assessments. Phi Delta Kappan, 91, 5, pp. 37-42. http://dx.doi. org/10.1177/003172171009100511

Phillippo, K. L. and Blosser, A. (2013). Specialty Practice or Interstitial Practice? A Reconsideration of School Social Work's Past and Present. Children \& Schools, 35, 1, pp. 19-31. http://dx.doi. org/10.1093/cs/cds039

Phillippo, K. and Stone, S. (2011). Toward a broader view: A call to integrate knowledge about schools into school social work research. Children \& Schools, 33, 2, pp. 71-81. http://dx.doi.org/10.1093/ cs/33.2.71

Raines, J. C. (2006). SWOT! A strategic plan for school social work in the twenty-first century. School Social Work Journal, 30, pp. 132-150.

Reardon, S. (2011). The widening achievement gap between the rich and the poor: New evidence and possible explanations. In Duncan, G. J. and Murnane, R. J. (eds.), Whither Opportunity? Rising inequality, schools and children's life chances. New York: Russell Sage, pp. 91-116.

Rothstein, R. (2004). Class and schools: Using social, economic, and educational reform to close the achievement gap. Washington, DC: Economic Policy Institute.

Rumberger, R. (2011). High school dropouts in the United States. In Lamb, S. et al. (eds.), School dropout and completion: International comparative studies in theory and policy. New York, NY: Springer, pp. 275-294.

Rutter, M. and Maughan, B. (2002). School effectiveness findings: 1979-2002. Journal of school psychology, 40, 6, pp. 451-475. http://dx.doi.org/10.1016/ s0022-4405(02)00124-3

Sedlak, M. W. (1997). The uneasy alliance of mental health services and the schools: An historical perspective. American Journal of Orthopsychiatry, 67, 3, pp. 349-362.

Sedlak, M. and Church, R. L. (1982). A history of social services delivered to youth. Washington, DC: US Department of Education, National Institute of Education. http://dx.doi.org/10.1037/h0080238

Shaffer, G. L. (2006). Promising school social work practices of the 1920s: Reflections for today. Children \& Schools, 28, 4, pp. 243-251. http://dx.doi.org/10.1093/ cs/28.4.243

Shepperd, S., Lewin, S., Straus, S., Clarke, M., Eccles, M. P., Fitzpatrick, R. and Sheikh, A. (2009). Can we systematically review studies that evaluate complex interventions? PLoS Medicine6, 8. e1000086. http://dx.doi.org/10.1371/ journal.pmed.1000086

Staudt, M. M., Cherry, D. J. and Watson, M. (2005). Practice guidelines for school social workers: A modified replication and extension of a prototype. Children \& Schools, 27, 2, pp. 71-81.

Stephan, S., Westin, A., Lever, N., Medoff, D., Youngstrom, E. and Weist, M. (2012). Do School-Based Clinicians' Knowledge and Use of Common Elements Correlate with Better Treatment Quality? School
Mental Health, 4, 3, pp. 170-180. http:// dx.doi.org/10.1007/s12310-012-9079-8

Stone, S. (2007). Child maltreatment, outof-home placement and academic vulnerability: A fifteen-year review of evidence and future directions. Children and Youth Services Review, 29, 2, pp. 139-161. http://dx.doi.org/10.1016/j. childyouth.2006.05.001

Stone, S., Shields, J. P., Hilinski, A. and Sanford, V. (2013). Association Between Addition of Learning Support Professionals and School Performance An Exploratory Study. Research on Social Work Practice, 23, 1, pp. 66-72. http://dx.doi. org/10.1177/1049731512464581

Substance Abuse and Mental Health Services Administration. NREPP: SAMSHA's National Registry of Evidence-based Programs and Practice. Available at: http://www.nrepp.samhsa.gov/. Accessed 30 June 2010.

Strompolis, M., Vishnevsky, T., Reeve, C. L., Munsell, E. P., Cook, J. R. and Kilmer, R. P. (2012). Educational outcomes in a system of care for children with emotional disturbance. American Journal of Orthopsychiatry, 82, 1, pp. 129-136. http://dx.doi.org/10.1111/j.19390025.2011.01126.x

Teich, J. L., Robinson, G. and Weist, M. D. (2008). What kinds of mental health services do public schools in the United States provide? Advances in school mental health promotion, 1(sup1), pp. 13-22.

Tyack, D. (1992). Health and social services in public schools: Historical perspectives. The Future of Children, 2, 1, pp. 19-31. http://dx.doi. org/10.2307/1602459

U. S. Department of Education, National Center for Education Statistics, Schools and Staffing Survey (SASS), "Public School Data File," 2007-08.

Warren, M. R. (2005). Communities and schools: A new view of urban education reform. Harvard Educational Review, 75, 2, pp. 133-173. 